\title{
GLORY OF WOMEN IN FAMILY (ISLAMIC FEMINISM PERSPECTIVE)
}

\author{
Kholifatur Rosyidah, S.Ag \\ 188610800088 \\ Muhammadiyah University of Sidoarjo \\ Email: Tazkiyahsabiluna@gmail.com
}

\begin{abstract}
:
Family is the basic foundation of the spread of Islam. In the family there is power that becomes control of the development of the family itself. Gender equality often occurs in a family, in this case the similarity between mother and father or commonly known as equality. In everyday life it is often disputed about the work of men and women that are expected to be in accordance with their nature. This view still revolves around biological factors where weak-bodied women should get light jobs while men who are physically strong should get jobs that show more power. This study focuses more on the glory of women in the family with an Islamic feminism perspective. This research method uses descriptive methods using a qualitative approach to describe data relating to the glory of women in the family. The research data is in the form of quotes, words, phrases, and story sentences. The source of the data in this study was the observation of several sakinah families in the Sidoarjo city area. The results of this study suggest that in Islam there is also an understanding of gender equality between men and women. This case is according to the instructions of the Qur'an and also Al-Hadist. There are also several rights for women to be glorified in their families. So women are not looked down on by their family members and are also not viewed negatively by family and society.
\end{abstract}

Keywords: Family, Islam, Glory, Women, Feminism, Gender Equality, Qualitative Descriptions.

\section{A. INTRODUCTION}

Humankind was created on earth to have the goal of becoming a Caliph Fil Ard and to become a devoted servant of God.

Humans get orders from God to preserve their species, develop civilization, and continue to improve the quality of human beings from generation to generation.

The duty of humans can create harmony, peace and security by always keeping together, differences, and provide benefits to fellow humans on earth.

So that humans are required to have knowledge, adab, and order of life so that humans can continue to develop from time to time. One way of that, humans do to develop through families.

Family is the basic foundation of the spread of Islam. The family means the smallest unit of society consisting of the head of the family and some people who gather and live somewhere under a roof in a state of mutual dependence.

The family has a merging process that is a process that has blood relations, marital relations, or relationships that occur in the life of one household, interact with each other and have their respective roles in order to create the defense of a 
culture.

The family is divided into three types, namely the nuclear family, the conjugal family, and the extended family. The nuclear family consists of husband, wife, and children. The conjugal family consists of adult partners (mothers and fathers) and their children who have interactions with relatives of one or two parents. Meanwhile, the extended family is more on the basis of the lineage above the original family, which includes the relationship between uncle, aunt, grandfather's family, and grandmother's family.

In the family there is power that becomes control of the development of the family itself. The power in question is patriarchal, matrix, and equalitarium. Patriarchal power is a family that has control on the father's side. Matriarchal is a family that has control on the mother's side. Meanwhile, the equalitarium family is a family that has control on the father and mother side. ${ }^{1}$

The family is very influential on the formation of character for each individual who is in it. The family is a small community which is the first cell for a large community. Family is also the first school for children, which through the cracks of the child absorbs the values of the skills, knowledge and behavior that are in it.

Families play a very important role in children's education, so anyone who is in the family sphere is required to behave according to morality and ethics in society, moreover according to the source of Islamic teachings namely the Qur'an and Hadith.

The family is a component that forms a society, the condition of a society is very dependent on the conditions of the families that make it up.

In recent years, gender equality often occurs in a family, in this case the similarity between mother and father or

\footnotetext{
${ }^{1}$ M. Quraish Shihab, Wawasan al-Qur'an, (Bandung: Mizan, 1998), h. 296
}

commonly known as equality. In Islam, the family becomes the place for the emergence of leaders who strive in the way of Allah, and the family becomes the origin of the seeds, whose will fight to continue the struggle of Rasullullah S.A.W.

Based on the statement above, then in a family there will be an activator who plays a big role, namely women (often referred to as mothers). Women have rights in the family

This right aims to make families built based on religion peacefully so that they can become a support and a place of refuge for their members and the foundation of community strength to obtain peace of life.

However, in this study more focused on the glory of women in the family with Islamic feminism perspective.

\section{B. RESEARCH METHODS}

This research method uses descriptive methods that are carried out through data collection in the field, which provides an overview of the glory of women in the family.

Descriptive method according to Sugiyono is a research method that aims to describe, explain the conditions that exist in the company based on facts, the characteristics of the population based on data that has been collected and then arranged systematically and then analyzed for conclusions.

This research approach uses a qualitative approach. The qualitative approach is done by describing existing data and then followed by analyzing the form of the glory of women in the family, especially in the perspective of Islamic feminism.

The research data is in the form of quotes, words, phrases, and story sentences. The source of the data in this study is the observation of several sakinah families in the Sidoarjo city area and conducting library studies in the library by reading and understanding several 
references to books, articles, and journals both online and offline.

The location of the study was in the Sidoarjo city area in Indonesia by looking at the thoughts of the sakinah family randomly to be interviewed regarding the glory of a mother in the family.

\section{RESEARCH RESULTS}

This research is expected to be useful and a reference for other researchers who want to explore and discuss research that is related to the perspective of Islamic feminism.

This research shows that in Islam there is also an understanding of gender equality between men and women. In this case according to the instructions of the Qur'an and also Al-Hadist.

Gender equality in question is a form of feminism. Feminism itself is a movement and ideology that fights for equality for women in politics, economics, culture, personal space and public space.

Feminism is an awareness of oppression and extortion of women in society, in the workplace and in the family, as well as the conscious actions of women and men to change the situation. Whereas according to Yunahar Ilyas, Feminism is awareness of gender injustice that afflicts women, both in the family and society.

Al-Qur'an also says that women and men are human beings who are created to complement and complement each other to achieve perfection in worshiping Allah S.W.T and also to the Messenger of Allah S.A.W.

The glory of women has also been contained in the Hadiths of the Prophet Muhammad, as in one of the following hadiths: Hadiths who affirm the obligation of the husband to pay attention to the rights of his wife, including hadiths in Shahih alBukhari and Muslims from the friend of Abu Hurairah Radhiallahu anhu, he said, "Rasulullah said:

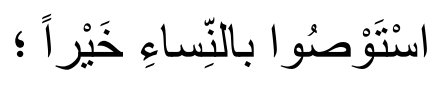

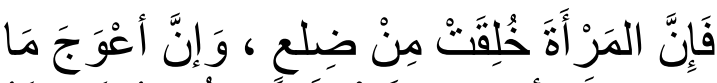

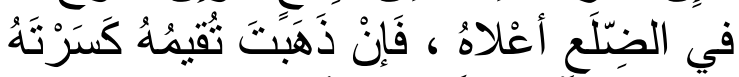

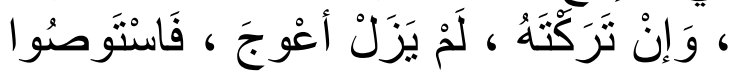
بالنِّساءِ

Which mean:

Accept my will to do good to women. Indeed they are created from ribs (which are bent). And the most crooked of ribs is the top rib. If you straighten it, you will break it, but if you leave it alone, it will be bent, then it will be OK for him.

\section{RESEARCH DISCUSSION Women's Glory in Islam}

The glory of women before the arrival of Islam is considered despicable. At that time women were considered not as humans. Greek society at that time considered women as a means of pleasure. Even Roman society gave rights to a father or husband to sell a daughter or his wife. Then the Arab community gave the right to a child to inherit his father's wife. They do not get inheritance rights and are not entitled to possess property.

Something similar also happened in Persia, the Indies and other countries. The Arab community at that time used to bury their daughters alive without sin and guilt, just because he was a woman!

Allah said about them in Surah An-Nahl verse 58:

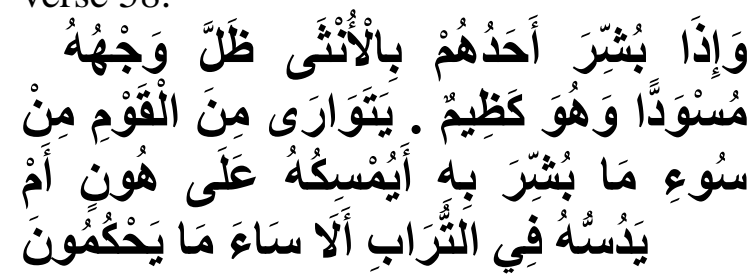

Which mean:

"And when someone of them was told by (the birth of) a daughter, his face was black, and he was very angry. He hid himself from the crowd, because of the bad news that was conveyed to him. Will he take care of him by bearing humiliation or will he bury him into the earth? Know, what a bad thing they set it. "

Based on the above events, then Allah revealed his revelation to the Messenger of Allah S.A.W to spread the 
religion of Islam so that humans at that time could change their mindsets and actions to better humanize human beings as well as possible.

So Rasulullah S.A.W made various efforts to combat all forms of injustice and guarantee every human right without exception. In God's word about how to treat women in Surah An Nisa verse 19:

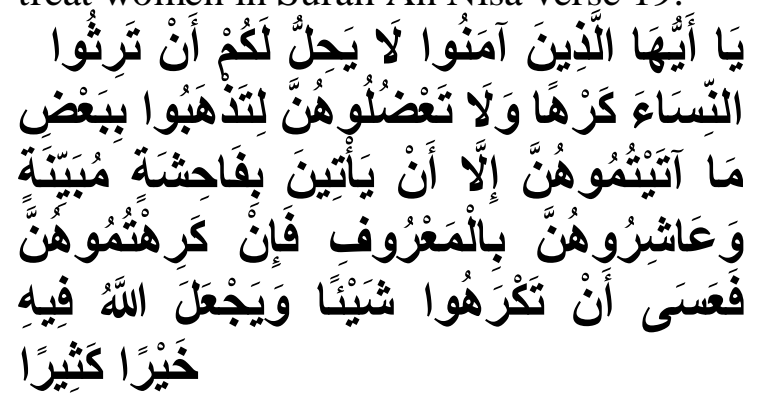

Which mean:

"O ye who believe, it is not lawful for you to destroy women by force, and do not trouble them because they want to take back some of what you have given him, except if they do a real abominable work. And associate with them properly. Then if you don't like them, (then be patient) because maybe you don't like something, even though Allah makes him a lot of goodness."

Rasulullah S.A.W also often reminds us of his words so that Muslims respect and glorify women. Among his words:

Which means:

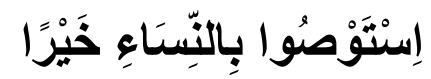

"I will remind you to do good to women." (HR Muslim: 3729)

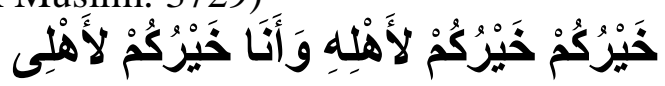

Which means:

"The best of you are the best of his wife, and I am the best of my wife." (Tirmidhi, pronounced saheeh by Al Albani in "ash-shahihah": 285)

Islam considers that women are a gift of God. With him men will get peace, birth and mind. From it will emerge positive energy that is very useful in the form of love, affection and life's motivation. Men and women become one entity in the household frame. Both help each other in realizing a comfortable and full of happiness, educating and guiding generations to come. Allah says in Surah Al Rûm verse 21:

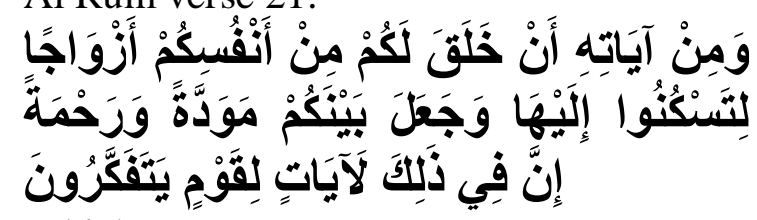

Which means:

"And among His signs is He created for you wives of your own kind, so that you will tend and feel secure to him, and He will make you love and affection. Indeed, there are indeed signs for those who think.

Allah also said that a woman becomes as wives, children and grandchildren, who gave good fortune.

Besides that, Allah also ber said in Surah Al Baqarah verse 187:

Which means:

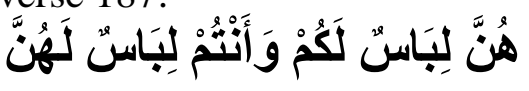

"They (wives) are clothes for you, and you are also clothes for them."

In Islam, the rights and position of women are explained and also guaranteed. Basically, everything that becomes a man's right is also his right wanita. His religion, his wealth, his honor, his reason and his soul are guaranteed and protected by Islamic law as men. The Qur'an says that women have the same rights as men in worship and get rewards in the Surah An Nisâ verse 124

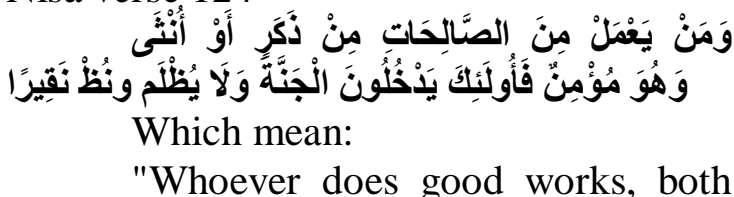
men and women, is a believer, they enter heaven and they are not persecuted even in the slightest."

The rights of women in question are as follows:

1) Women also have the right to be involved in deliberations in matters of breastfeeding

2) Women have the right to complain about their problems to the judge

3) Women are male partners in the role of illiterate and other worshipers

4) Women have rights to men, as men do to them. 
In addition to guaranteeing the rights of women, Islam also protects women from all things that can tarnish their honor, bring authority and dehumanize them.

Like a pearl which is expensive, Islam places it as a noble creature that must be guarded. On this basis, then a number of rules are set by Allah S.W.T. And for the next, women can carry out their strategic role as educators of future generations.

According to one Islamic scholar, Muhammad Tahhir 'Ashr Rahimahullah, has argued that Islam was very concerned about the goodness of women's affairs. How not, because women are half of the human kind, the first educator in mental education before the other, mind-oriented education so that he is not affected by any bad influences, and also the heart so that he is not influenced by Satan's influence.

Islam is a religion of Shari'a and rules. Therefore he came to improve the condition of women, to elevate his level, so that Muslims (with their role) have readiness to progress and lead the world. There are certain rules for women that are rules in clothes that cover a woman's entire body. This rule is different from men. Allah ordered so that they could be saved from the malevolent spies of men and not be a slander for them.

Women are also commanded by God to protect their honor in the presence of men who are not their husbands by not mingling with them, more staying at home, keeping their eyes, not using fragrances when leaving the house, not lowering their voices and others.

All the above Shari'a are stipulated by Allah in order to protect and glorify women, while guaranteeing a good and clean order of life from the deviant behavior that arises due to the destruction of the social boundaries between men and women. The outbreak of adultery and the occurrence of sexual harassment are among the phenomena that are caused because women do not maintain the rules of Allah above and men as leaders and those responsible are negligent in applying the laws of God to women.

Islam gives women some privileges that are not owned by men, and provides opportunities for women to be active in various fields. The oath of allegiance (baiat) of the women to the Prophet Muhammad was proof of their role in politics.

Muslim women are also active on the battlefield to treat wounded soldiers, or even join in fighting against the enemy if the situation is as urgent as the Nasibah did during the Uhud war. The first person who died (martyr) defended Islam was a woman, namely Sumayah Mother Ammar bin Yasir. In fact, even after Raslullah SAW's death, women emerged who mastered the knowledge of both religious and other sciences. Based on that statement above, there is also the Advent of female hadith narrators, women who achieve the degree of ijtihad. The scientific tradition of religion among women continues to grow until now, and even in Iran there are now many women who have achieved the degree of ijtihad (called the mujtahidah), or experts in the field of irfan (Islamic esiterism).

Islam has really raised the dignity and dignity of women and glorified them with glory that has never been done by other religions. Women in Islam are male twin brothers; their best is the best for their family.

\section{Women's Glory in the Perspective of Islamic Feminism}

Islamic rationality is the basis of Islamic modernity and believes that Islam has provided modern principles.

Islam views arbitrariness against women as something which is contrary to Islamic principles. This is because in Islam is a religion that promotes equality. 
Islam believes that feminism is also a part of it to be a form of equality between men and women. ${ }^{2}$

An expert on Islam, Syaikh Abduh believes there are eight foundations in religion. Some of these points, among others, break down religious sovereignty (qalb al-sulthah al-diniyah), which means that no one can master the sovereignty of one's faith except Allah SWT and the Prophet Muhammad and protect da'wah to avoid chaos.

Syaikh Abduh also believes that the war that Islam advocates is an effort to defend themselves from attacks but this teaching does not deny the teachings to forgive opponents. He also forbade the concept of bigotry or excessive religion. Thus, Shaykh Abduh also put forward about women to have rights and obligations in Islam and in families even though men are leaders of the household or qawwam, but like the social life of the country, deliberation is still needed.

Contrary to the Arab Jahiliyah tradition that regulates the lives of women until marriage, Shaykh Abduh considers that women have the right to marry the man he loves without coercion.

Based on the statement above, feminist Muslims are female partners. One popular feminist Muslim expert is Qasim Amin. Raised by a father of OttomanOttoman descent and an Egyptian mother in the middle class, Qasim Amin finally became a lawyer when he was 22 years old. He often wrote articles on reform and he often invited controversy up to now.

His famous work is Tahrir, alMar'ah (Women's Liberation) which was published in 1899. This book discusses two major perspectives, namely education and social reform and religious thought reform.

In this work it is very visible that Qasim Amin was inspired by the concept of Syaikh al-Thathawi's liberalism and

\footnotetext{
${ }^{2}$ Laela Ahmed, Wanita dan Gender dalam Islam: Akar Historis Perdebatan Modern, (Jakarta: Pilar Media, 2005), h. 38
}

Sheikh Abduh's Islamic rationalism. Then he wrote the book al-Mar'ah al-Jadidah (Modern Woman).

However, Qasim Amin was not the first person to talk about the need for education and freedom for women. Women's intellectual movement in the field of writing began with several figures in the Syam region (Syria, Lebanon, Palestine and Jordan).

Qasim Amin believed that true freedom is freedom that can bring all thoughts, publish every stream, and welcome every idea.

Quoting Muhammad Guntur Romli from his book "Muslim Feminists", a feminist Muslim is a "female partner" in upholding gender equality which is a jihad in Islam. These intellectual figures are very necessary to spread the tolerance of Muslims and other religious people.

As reviewed by Syaikh Abduh, Islam has a modern foundation and naturally the concept of feminism is a concept that must be fully embraced by all Muslims and Muslim women in Indonesia. Understanding feminism should not be used as an enemy. No need for us to hate something we can't even understand.

\section{Glory of Women in the Family}

Women have a dual role, in the household and outside the home where both roles require time and full attention to make a woman's career journey seem left behind and marginalized compared to men.

A woman has three great roles that she does in the family with the following details:

1) Women as Wives Become Partners, Motivators and Husband Advisers

The wife became a partner, became a friend who could be invited to discuss the problems faced by the husband so that when the husband faced a fairly heavy problem, the wife not only became a good listener but also provided solutions to the problem, the burden felt by the husband would decrease. 
The present wife gives encouragement and motivation to the husband so that the husband is excited. Then when the husband is under the flow of the black world, the wife appears as an advisor to the husband who cannot escape the mistakes he sometimes does not realize, this is where the wife's duty to advise her husband not to fall into the wrong path.

2) Women as Mothers Become Educators at the Family Institute

The role of women as mothers, not only preparing a food menu for their children but also a figure of educators at family institutes, because in the mother's family the closest to the child, the inner birth bond that the child has with his mother, and more child interaction with his mother so that the mother's figure becomes a role model for her children. Mother nurtures, educates, and guides young, moral and intellectual generations who are ready to color this beloved Pancasila country in the future.

3) Women As Communities Become State Poles

Women are the basic foundation of the glory of a society because women have a strategic role in the success of nation building, if there are good women, then the country is good, and if the women are damaged, then the country will be damaged.

Thus, the duty of a wife as a companion to her husband and mother to her children is to hold the mandate as a regulator of affairs in the home for her husband and children. He will later be asked about his obligations. This is the important role of a woman, as a household manager in her family. Women already have own mandate and duty that must be carried out as well as possible.

From what was stated above, it is clear that the key to the success of a child in his life is very dependent on the mother.

Mother's attitude that is full of affection, gives opportunity to children to enrich their experience, receive, appreciate and can be a positive example for their children, will have a great influence on children's personal development.

\section{E. CONCLUSION}

If family life is likened to a building, that is for the sake of maintaining the building from the impact of storms and earthquake shocks. Then it must be established on a strong foundation with sturdy building materials and adhesive threads that must be truly qualified. The foundation of family life is religious teachings, accompanied by physical and mental readiness. The adhesive fabric for the family building is the right and obligation that God has given to his husband, wife and children.

Women as wives, in families also face a huge mental burden similar to what their husbands feel, from before sunrise to sunset to clean the house so that the husband stays at home, arranges healthy food, prepares clothes, and educating children. Everything is done sincerely for the sake of the happiness of the household, but in reality nowadays the appreciation of a wife is often not comparable to what has been done.

A very important role in maintaining a family life starts from a woman, who will later become the first teacher for her children. In the hands of a woman, who is usually called the mother, the success of education in a family is carried out successfully.

This can be seen with the success of education in their children. Even though the figure of the father is not too dominant in terms of family education, his participation cannot be ignored.

Mothers play an important role in educating their children, especially in infancy. Therefore the wife is a source of manners, because the woman who has accepted the existence of this type of human being, has since appeared in the womb, until finally the man is large in his lap and swing. 
The existence of a wife recognized by the Qur'an is an indisputable reality. Even in the Al-Qur'an there are five letters whose names indicate to women, such as al-Nisa', al-Talaq, al-Mujadilat, alMumtahanat and those who mention their names specifically like Maryam.

In addition to recognition of the existence of women like that, the Qur'an also regulates their lives so as not to misstep in living their lives and lives in the world, so that they will be able to achieve the happiness of the world until the hereafter. The role of a wife in this life is very important.

In the context of the family, Islam views women as partners, partners, and male friends in carrying out their duties to serve Allah and become caliphs on earth through the division of labor between the two. In addition, Islam does not view one's role as a determinant of the quality of one's life. The measure of glory is piety which is measured qualitatively, which is as good as - not as much as - someone is fearful of Allah S.W.T is in harmony with the suras in the Qur'an surah al-Hujurat verse 13:

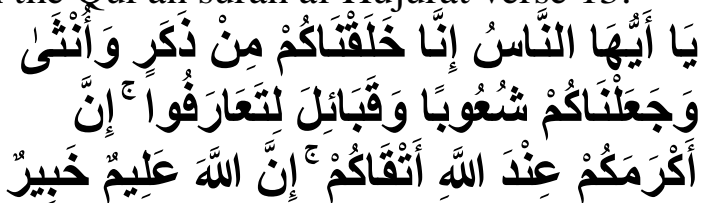

Which mean:

$O$ mankind, verily We created you from a man and a woman and made you nations and tribes so that you would know one another. Surely the most noble among you is by Allah the one who has the most fear among you. Lo! Allah is Knower, Knower.

Allah also said in surah al-Mulk verse 2

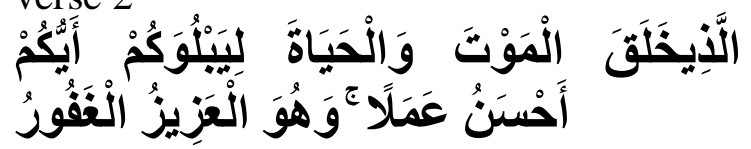

Which mean:

Who makes death and life, so that He may test you, who among you is better deeds. And He is Mighty, Forgiving.

Al-Qur'an provides a very positive image of women. This can be seen in the Koran's description of women. The Koran never gives discriminatory signals to women. Women are placed in equal positions with men. Have the same obligation before God to do good and reject evil, and the same obligation of worship.

So in this study it was found that in Islam there was also an understanding of gender equality between men and women. This is also reinforced in the Qur'an and Al-Hadist. Where mentioned also some rights for women to be glorified in their families.

Therefore, women are not looked down on by their family members and are also not viewed negatively by family and society.

\section{BIBLIOGRAPHY}

Ahmed, Laela. 2005. Wanita dan Gender dalam Islam: Akar Historis Perdebatan Modern, Jakarta: Pilar Media.

Hambal, Muhammad. 2015. "Deresan" Program the Mastery of ArabicClassic Book at Pondok Pesantren Karangasem Lamongan East Java Indonesia. Journal of Social Sciences and Humanities, Vol. 1, No. 2, pp. 125-130

Miharso, Mantep. 2004. Pendidikan Keluarga Qur'ani, Yogyakarta: Safiria Insania Press.

Sahiron Syamsuddin. 2010. Studi AlQur'an: Metode dan Konsep, Yogyakarta: ELSAQ Press.

Umar, Nasaruddin. 2001. Argumen Kesetaraan Jender Perspektif alQur'an, Jakarta: Paramadina.

Wadud, Amina. 2001. Qur'an Menurut Perempuan: Meluruskan Bias Gender dalam Tradisi Tafsir, Terj. Abdullah Ali, Jakarta: Serambi Ilmu Semesta. 
Yusuf, Ali Ash-Shubki. 2010. Fiqh Keluarga, Jakarta : Amzah.
Zaid, Syaikh Bakar bin Abdullah Abu. 2003. Menjaga Citra Wanita Islam, terj.Gunaim Ihsan, Uzeir Hamdan, Jakarta: Darul Haq. 